sive sweat causes incomplete recording of actions probably pass unrecognized. the finger impression. Further, "white lines" are common in normal people, particularly in those following certain occupations-for example, bricklayers, cement workers and housewives. These lines quickly disappear during periods of interruption of the relevant employment. Improvements observed during periods of treatment probably relate to concomitant change in occupation rather than to the dietary management.-We are, etc.,

W. MORRICE MCCRAE G. SANDOR

A. P. SANGan

Royal Hospital for Sick Children, Edinburgh

R. STALKER Detective Inspector,
Edinburgh City Police

1 Home Office, Instructions in the Method of Toking Finger and Palm Prints, London, H.M.S.O.,

\section{Halothane Hepatitis}

SIR,-Though perhaps not surprised I was nevertheless a little disheartened to read the various letters (17 April, p. 166 and 29 May, p. 523) which followed the publication of our paper on halothane hepatitis (20 February, p. 448). For the same old arguments based on clinical impression and selected papers from the literature are again put forward. The findings of the National Halothane Study ${ }^{1}$ based on a retrospective analysis of data from 34 centres have to be interpreted with considerable caution, as was stressed in the original publication, and on many occasions since by some members of the panel.

There can be no doubt about the existence of halothane hepatitis as a distinct entity. I will not repeat the various features summarized in our paper which distinguish it from viral hepatitis. They include immunological abnormalities as well as distinct differences in histological appearances on both light and electron microscopy. These have also been the subject of a recent and detailed appraisal by Professor Sheila Sherlock. ${ }^{2}$ Even more damning evidence comes from the effect observed in patients, anaesthetists, and even a worker in a factory making halothane, when re-challenged with this agent. The differences between the histological appearances of viral hepatitis and of that due to halothane are also stressed in a recent paper from America $^{3}$ in which the authors refute the hypothesis that halothane hepatiti represents a coincidental viral hepatitis or aggravation of a viral infection by the anaesthetic. The appreciation of these histological changes will of course depend on the experience of the pathologist in this field. Indeed, this is well illustrated by the letter of Dr. J. D. Hill (17 April, p. 166) in which he questions the diagnosis of one of the cases included on our report partly on the basis of a histological report described as showing advanced biliary cirrhosis. But when this material was most carefully reviewed by us and by independent observers the appearances were clearly those of submassive hepatic necrosis with some areas of surviving tissue, entirely consistent with a halothane aetiology. Of course it may be difficult to prove the diagnosis in an individual patient for the relevant tests are often not done at the right time and many of the milder re-
If all those clinicians, pathologists, and immunologists with special experience of liver dicease are all agreed on the existence of halothane hepatitis, and I doubt if there is a single hepatologist throughout the world who is not, why do anaesthetists not accep it and then tackle the problem in a more constructive manner? Although the overal incidence of fatal hepatic necrosis following its use may indeed be low, two-thirds of the fatal cases have followed multiple exposures and it is these which could have been prevented. An acceptance of its existence together with more detailed observation and laboratory investigation of patients having multiple anaesthesia would allow diagnosis of the first and often milder reaction-a warning sign not to be ignored. Even if such a reaction cannot be proved beyond doub surely it is only wise to ensure that these patients are not exposed again to halothane? Such a policy would in no way negate the setting-up of a properly and controlled prospective trial with adequate laboratory and other objective criteria. Initially the trial should be restricted to certain diagnostic groups such as those patients likely to need multiple anaesthesia, who are at the greatest risk.-I am, etc.,

ROGER WILLIAMS

\section{Liver Unit,}

King's College Hospital

1 Committee on Anaesthesia, National Academy of Sciences and National Research Council, Fourna of the

2 Sherlock, S., Gut, 1971, 12, 324.

Uzunalimoglu, B., Yardley, J. H., and Boitnott. J57. K., American fournal of Pathology, 1970, 61,

\section{Sleep of Enuretics}

SIR,- - In his review on childhood enuresis (26 December, p. 787) Dr. R. Meadow unfortunately perpetuated some erroneous observations when he stated, "E.E.G. studies have shown that wetting usually occurs when sleep is light or the child is awake." These views arose from the reports of Ditman ${ }^{1}$ and Bental. ${ }^{2}$ However, Pierce ${ }^{3}$ found that enuresis occurred during slow wave sleep.

Sleep is composed of two contrasting physiological states which alternate regularly. Slow wave sleep is a cyclical state created by transitions between contiguous stages of slow wave sleep, demarcated by spindling fast activity (sleep spindles) and large slow waves in the encephalogram. Stage I or drowsiness, contains minimal slow waves, while Stage IV-the trough of the cyclecontains maximal slow activity. Normally there are four or five cycles during a night's sleep. Between cycles, episodes of rapid eye movement (R.E.M.) sleep occur. The bulk of dreaming occurs in R.E.M. sleep.

Gastaut ${ }^{4-6}$ has described an "enuretic episode" in children. Beginning in Stage III or IV slow wave sleep-that is, near the trough of the cycle, small body movements and muscle twitches associated with respiratory irregularities and decreased skin resistance, preceded micturition.

However, as Schiff described enuretic episodes in three Army recruits during drowsiness, I have investigated the sleep of a group of six adolescent subjects (aged 12-19) and three adult subjects (aged 22-35). A total of 19 enuretic episodes were recorded during 47 nights. Initially bed electrodes were used to signal enuresis, but latterly a soft rubber collecting tube system was used. Without exception, enuresis occurred during slow wave sleep, generally starting in Stage III or IV. Tachycardia and muscle twitches preceded enuresis.

Enuresis in the adult and adolescent does not appear to be different from that of the child. Gastaut ${ }^{6}$ and Broughton ${ }^{9}$ have demonstrated physiological differences between enuretic children and controls. Bladder contractions in the normal child are limited to body movements and arousal. However, in enuretic children' spontaneous bladder contractions were more common in Stage IV sleep and a series of contractions preceded micturition. Broughton also found increased pulse rates during sleep in enuretic children. Using cerebral evoked potentials, he was also able to show a "carry over" effect from sleep into arousal, which may account for the stories that enuretic children can be very difficult to rouse.-I am, etc.

J. I. Evans

Sleep Laboratory,

of Psychiatry,

1 Ditman, K. S., and Blinn, K. A., American Fournal of Psychiatry, 1955, 111, 913 American
Bental, E., fournal of Psychosomatic Research, 1961, 5, 116

3 Pierce, C. M., Whitman, R. M., Maas, J. W. and Gay, M L., Archives of General Psychiatry, $1961,4,166$

Neurologie, $1963,109.247$.

Neurologie, $1963,109.247$. encephulography and Clinical Neurophysiology, 1964, 16. 625 .

6 Gastaut, H., and Brouehton, $\mathrm{R} \mathrm{J}$., Recent

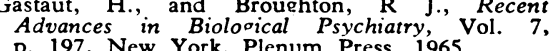
P. 197, New York, Plenum Press, 1965. Diseases, 1965, 140, 397.

8 Broughton, R. J., Science, 1968, 159, 1070

SIR,-We have recently treated two patients with paraquat poisoning. The first patient, a man of 35 , deliberately ingested $2 \mathrm{~g}$ of paraquat as Weedol granules. He is well and back at work two months after admission. The second, a man of 23, accidentally ingested a mouthful of commercial concentrate and is now recovering rapidly 49 days after admission. A more detailed report will be available after a longer period of follow-up.

If the concentrate is not going to be made unavailable for general use as Dr. A. A. H. Lawson (26 June, p. 767) suggests, we feel strongly that the manufacturers and users of paraquat-containing weedkillers must be compelled to provide more adequate safeguards against accident, and that its extremely poisonous nature must be emphasized on all containers. However, the above cases and other reported survivals suggest that the outlook is not as gloomy as expressed in the lay and medical press. Headlines such as "Doomed-a boy who drank pop bottle poison" and phrases such as "waiting unsuspecting for death" (Sun, 15 and 17 June 1971) caused unnecessary anxiety to our two patients.-We are, etc.,

A. J. L. Cole J. B. HAWKINS P. P. MAYER

Regional Haemodialysis Unit,

East Birmingham Hospital Birmingham 9 